التقدير الطيفي للاوكسيميتازولين هيدروكلوريد بشكله الحر وفي مستحضراته الصيدلانية باستخدام تفاعلات الأزوتة والاقتران

$$
\text { كلية التربية للعلوم الصرفة الكيمياء عبد العليم زكريا }
$$

Rawaazakaria72@gmail.com DOI: $10.33899 /$ edusj.1999.163319

$$
\text { جاميل نمير عبيد آغا كلية العلوم الكيمياء }
$$

Aseelagha@gmail.com thabetsaeed@gmail.com

$$
\begin{aligned}
& \text { ثابت سعيد الغبثة } \\
& \text { قسم الكيمياء } \\
& \text { كلية التربية للعلوم الصرفة }
\end{aligned}
$$

$$
\begin{array}{cc}
\text { الاستلام } & \text { القبول } 04 \\
2013 / 06 & \text { / } 05
\end{array}
$$

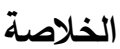

يشمل هذا البحث اقتراح طريقة طيفية دقيقة وبسيطة لتقديرالاوكسيميتازولين هيدروكلوريد في المحلول المائي تعتمد الطريقة على تفاعل الاوكسيميتازولين هيدروكلوريد مـع الكاشف المؤزوت حامض السلفانيلك بوجود هيدروكسيد الصوديوم، لتكوين

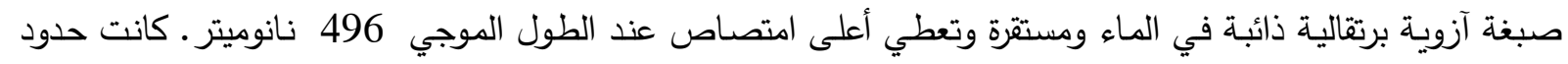

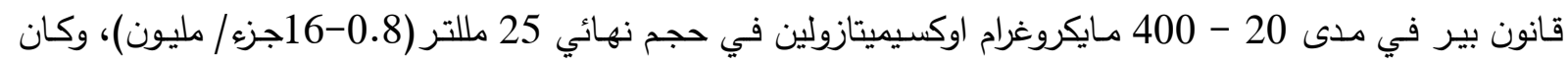

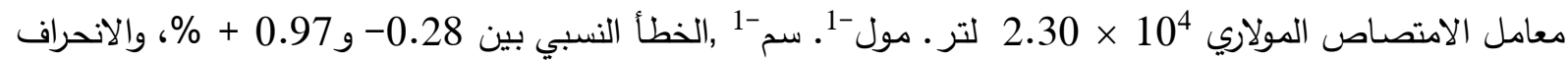

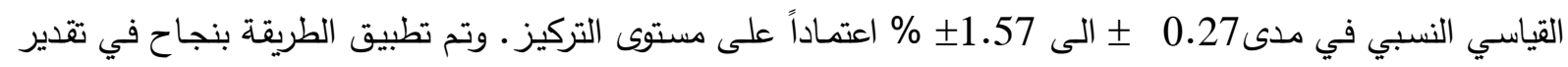
الاوكسيميتازولين في مستحضرين دوائيين.

الكلمات المفتاحية: التقدير الطيفي ، الأزوتة والاقتران ، الاوكسيميتازولين هيدروكلوريد ، حامض السلفانيلك. 


\title{
Spectrophotometric Determination of Oxymetazoline Hydrochloride in Pure and Pharmaceutical Preparations Using Diazo-coupling Reaction
}

\author{
Thabit S. Al-Ghabsha \\ Department of Chemistry \\ College of Education \\ for Pure Science \\ University of Mosul \\ thabetsaeed@gmail.com \\ DOI: $\underline{10.33899 / \text { edusj.1999.163319 }}$
}

\author{
Aseel N. Obedagha \\ Department of Chemistry \\ College of Science \\ University of Mosul \\ Aseelagha@gmail.com
}

\author{
Rawaa A. Zakaria \\ Department of Chemistry \\ College of Education \\ for Pure Science \\ University of Mosul \\ Rawaazakaria72@gmail.com
}

Received

$04 / 03 / 2013$
Accepted

05 / $06 / 2013$

\begin{abstract}
A ccurate and simple spectrophotometric method has been suggested for the determination of oxymetazoline hydrochloride $(\mathrm{OMCl})$ in aqueous solution is developed. The present process included coupling of $\mathrm{OMCl}$ with diazotized sulphanilic acid reagent in the presence of sodium hydroxide. The orange colored azo dye formed very stable and soluble in water gives maximum absorption at $496 \mathrm{~nm}$. The lineratey is obeyed over the range $20-400$ $\mu \mathrm{g} / 25 \mathrm{ml}\left(0.8-16 \mu \mathrm{g} \cdot \mathrm{ml}^{-1}\right)$ the molar absorptivity is equate to $2.30 \times 10^{4} 1 . \mathrm{mol}^{-1} \mathrm{~cm}^{-1}$. The proposed method has been used to the determination of $\mathrm{OMCl}$ in two formulations with satisfactories results.
\end{abstract}

Keywords: Spectrophotometric determination, Diazotization, Oxymetazoline hydrochloride, Sulphanilic acid.

\section{Introduction}

The hydrochloride salt of oxymetazoline is 3- [(4,5-dihydro-1H-imidazol-2-yl)methyl]-6(1,1-dimethylethyl)-2,4-dimethyl-phenol hydrochloride $(\mathrm{OMCl})$ [1], it is a sympathomimetic agent with marked $\alpha$-adrenergic activity has been introduced in some nasal solutions [2]. $\mathrm{OMCl}$ is applied to treat epistaxis and eye redness according to minor irritation [3,4].

The large doses of $\mathrm{OMCl}$ may cause hypotension, presumably because of a central clonidine-like effect[5].

Various procedures have been illusterated in litreture for the determind is: tittrimetric method[6], ion selective membrane electrode[7], chromatography[8-10] and flow injection[11]. Also, spectroscopy techniques have been used for determination of $\mathrm{OMCl}$ as pure and in various formulations different reagents such as 2,6-dichloroquinone-chlorimide[12] 2,4,6-tris(2-pyridyl)5-triazine[13], 1,10-phenanthroline[14], 3,5-dinitrosalicylic acid [15], and 4-aminoantipyrine [16].

Our aim is to evaluate a simple spectrophotometric method for the determination of $\mathrm{OMCl}$ as pure and in pharmaceutical drop formulations included coupling with diazotised sulphanilic acid in an alkaline medium of $\mathrm{NaOH}$. The product of orange azo dye formed proves to be intense, water- soluble and stable. 


\section{Apparatus}

\section{Materials and Methods}

Shimadzu UV-Vis.Recording spectrophotometric had been used in measurement of absorbance using 1-cm silica cells.

\section{Reagents}

chemical and solvents are chosed with high purity.

Working OMCl solution, $100 \mu \mathrm{g} / \mathrm{ml}$. A $0.01 \mathrm{~g}$ of $\mathrm{OMCl}$ is dissolved in distilled water and then volume is completed to $100 \mathrm{ml}$ in a calibrated flask.

Diazotised sulphanilic acid reagent solution, 30mM. A $0.5190 \mathrm{~g}$ of sulphanilic acid is dissolved $75 \mathrm{ml}$ of distilled water and the mixture is heated until the clear solution is obtained, then $1 \mathrm{ml}$ of hydrochloric acid (conc.) is added, the mixture is left in ice bath at $0-5^{\circ} \mathrm{C}$ and $0.207 \mathrm{~g}$ sodium nitrite is added and stirred vigorously and then the volume completed to $100 \mathrm{ml}$ in a volumetric flask using cooled distilled water, and is stored in refrigerator. This solution is prepared freshly each day [17].

Alkaline solution of $\mathrm{NaOH}(1 \mathrm{~N})$, is prepared byThis solution is prepared by appropriate dilution of the concentrated (Fluka) solution with distilled in a plastic container.

Nazodrin drops, $(100 \mu \mathrm{g} / \mathrm{ml})$. Three containers of drug (each contains $10 \mathrm{ml}$ of $0.05 \% \mathrm{OMCl}$ ) are mixed, then $20 \mathrm{ml}$ of the above solution was diluted with distilled water to $100 \mathrm{ml}$ in a volumetric flask to prepare a solution of $100 \mu \mathrm{g} / \mathrm{ml} \mathrm{OMCl}$.

Oxymet drops, $(100 \mu \mathrm{g} / \mathrm{ml})$. Provided from the Pharaonia pharmaceuticals.

Three containers of drug (each contains $15 \mathrm{ml}$ of $0.025 \% \mathrm{OMCl}$ ) are mixed, then $40 \mathrm{ml}$ of the above prepared solution was diluted to $100 \mathrm{ml}$ by adding distilled water in a volumetric flask .

\section{Procedure and calibration graph.}

To a series of $25 \mathrm{ml}$ volumetric flasks add $20-500 \mu \mathrm{g}(0.8-20 \mathrm{ppm})$ of $\mathrm{OMCl}, 0.5$ $\mathrm{ml}$ of diazotised sulphanilic acid $(30 \mathrm{mM})$ and $1 \mathrm{ml}$ of $1 \mathrm{~N} \mathrm{NaOH}$ are then added and the volumes are diluted to the mark using distilled water as a slovent. After 10 minutes the A are read virsus a reagent blank at $496 \mathrm{~nm}$ using $1-\mathrm{cm}$ cell. The linearity is over the range 20 to $400 \mu \mathrm{g} / 25 \mathrm{ml}(0.8-16 \mathrm{ppm})$ (Fig.1). The molar absorptivity is found to be $2.30 \times 10^{4} 1 . \mathrm{mol}^{-}$ ${ }^{1} . \mathrm{cm}^{-1}$

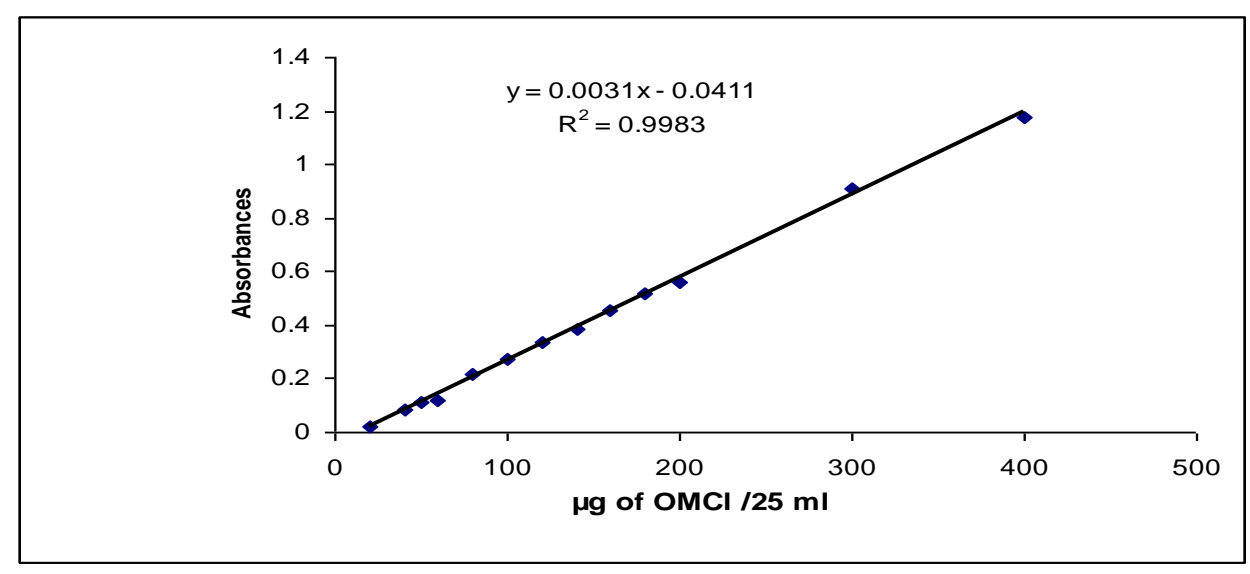

Fig.1. Calibration curve of OMCl determination

\section{Results and Discussion}

A $100 \mu \mathrm{g}$ of $\mathrm{OMCl}$ has been taken and final volumes are brought to $25 \mathrm{ml}$ with distilled water in subsequent experiment 
Absorption spectra.

When $\mathrm{OMCl}$ in aqueous solution is treated with diazotized sulphanilic acid reagent solution, an absorption peak is obtained showing an intense orange dye with maximum absorption at $496 \mathrm{~nm}$. The reagent blank shows no absorption at this wavelength (Fig.2).

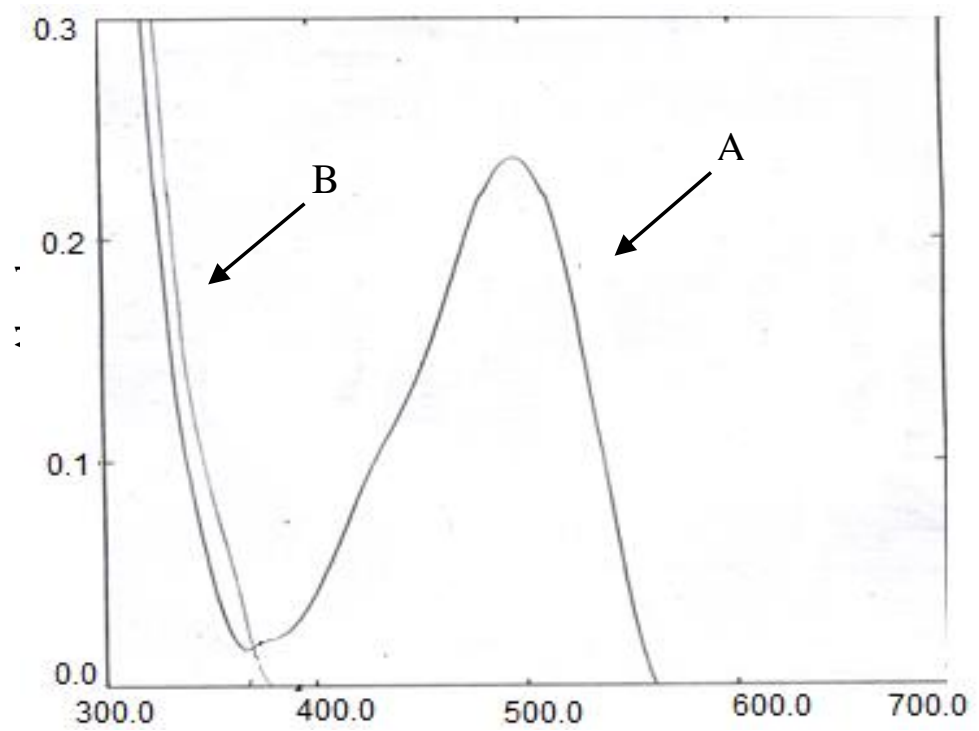

Fig.2:Absorption spectrum of OMCl with diazotized sulphanilic acid at $496 \mathbf{~ n m}$ (A) the azo dye against blank, (B) blank against distilled water

Study of the optimum reaction conditions. All parameters effecting and related to orange azo dye have been optimized .

Effect of base. The preliminary experiments have shown that the azo dye develops only completely in using base solution. Different amounts of bases (strong and weak) have been used (Table1).

Table 1. Effect of base on the A and color contrast

\begin{tabular}{|c|c|c|c|c|c|c|c|c|}
\hline \multirow{2}{*}{$\begin{array}{c}\text { Alkaline } \\
\text { solution } \\
(1 N) \\
\end{array}$} & \multirow{2}{*}{ Variable } & \multicolumn{7}{|c|}{ A / $\mathrm{ml}$ of various base used } \\
\hline & & 0.1 & 0.3 & 0.5 & 0.7 & 1 & 1.2 & 1.5 \\
\hline \multirow{2}{*}{$\mathrm{NaOH}$} & A & 0.283 & 0.271 & 0.259 & 0.247 & 0.263 & 0.199 & 0.161 \\
\hline & $* \Delta \lambda, \mathrm{nm}$ & 112 & 113 & 198 & 202 & 202 & 202 & 202 \\
\hline \multirow{2}{*}{$\mathrm{KOH}$} & $\mathrm{A}$ & 0.119 & 0.127 & 0.137 & 0.162 & 0.206 & 0.166 & 0.163 \\
\hline & $\Delta \lambda, \mathrm{nm}$ & 114 & 114 & 192 & 192 & 196 & 198 & 198 \\
\hline \multirow{2}{*}{$\mathrm{Na}_{2} \mathrm{CO}_{3}$} & A & \multirow{2}{*}{\multicolumn{7}{|c|}{ No color contrast }} \\
\hline & $\Delta \lambda, \mathrm{nm}$ & & & & & & & \\
\hline \multirow{2}{*}{$\mathrm{NaHCO}_{3}$} & $\mathrm{~A}$ & \multirow{2}{*}{\multicolumn{7}{|c|}{ No color contrast }} \\
\hline & $\Delta \lambda, \mathrm{nm}$ & & & & & & & \\
\hline
\end{tabular}

$* \Delta \lambda=\lambda_{\max } \mathrm{S}-\lambda_{\max } \mathrm{B} \quad$ where $\mathrm{S}=$ The azo dye and $\mathrm{B}=$ The Blank

The results in Table 1 indicated that $1 \mathrm{ml}$ of $1 \mathrm{~N}$ sodium hydroxide is the more suitable amount which gives a high values of colour contrast. 


\section{Effect of diazotized sulphanilic acid reagent amount.}

Various volumes of the diazotized sulphanilic acid $(30 \mathrm{mM})$ are tested, the results indicate that using $0.5 \mathrm{ml}$ of diazotized sulphanilic acid reagent solution gives maximum A of the complex at $496 \mathrm{~nm}$ and the volume is considered as an optimum value (Table 2).

Table 2. The optimize amount of diazotised sulphanilic acid

\begin{tabular}{|c|c|}
\hline $\begin{array}{c}\text { Ml of diazotised sulphanilic acid reagent } \\
\text { solution (30 } \mathbf{~ m M})\end{array}$ & Absorbance \\
\hline 0.05 & 0.144 \\
\hline 0.1 & 0.231 \\
\hline 0.25 & 0.242 \\
\hline 0.5 & 0.272 \\
\hline 1.0 & 0.266 \\
\hline 1.5 & 0.215 \\
\hline 2.0 & 0.122 \\
\hline
\end{tabular}

\section{Effect of surfactant}

Three orders by using $1 \mathrm{ml}$ of various types of surfactants have been studied. The effects of different surfactants on the colour intensity are showed that no useful effect and a loss in colour intensity are observed. Therefore, it has been recommended to eliminate the use of surfactants in the subsequent experiments (Table3).

Table 3. Effect of surfactants

\begin{tabular}{|c|c|c|c|c|c|c|}
\hline \multirow{3}{*}{ Surfactant used } & \multicolumn{6}{|c|}{ A*/ order** of addition } \\
\hline & \multicolumn{2}{|c|}{$\mathbf{I}$} & \multicolumn{2}{|c|}{ II } & \multicolumn{2}{|c|}{ III } \\
\hline & $\mathbf{A}$ & $* * * \Delta \lambda$ & $\mathbf{A}$ & $\Delta \lambda$ & $\mathbf{A}$ & $\Delta \lambda$ \\
\hline CTAB, $1 \times 10^{-3} \mathrm{M}$ & 0.075 & 204 & 0.080 & 202 & 0.098 & 204 \\
\hline SDS, $1 \times 10^{-3} \mathrm{M}$ & 0.258 & 198 & 0.269 & 200 & 0.262 & 198 \\
\hline Triton X-100, 1\% & 0.181 & 206 & 0.176 & 206 & 0.210 & 208 \\
\hline
\end{tabular}

\footnotetext{
* Absorbance without surfactant $=0.273$

** $\quad$ I. $\mathrm{OMCl}(\mathrm{O})+$ Surfactant $(\mathrm{S})+$ Diazotised sulphanilic acid $(\mathrm{R})+\mathrm{NaOH}(\mathrm{OH})$

II. $\mathrm{O}+\mathrm{R}+\mathrm{S}+\mathrm{OH}$

III. $\mathrm{O}+\mathrm{R}+\mathrm{OH}+\mathrm{S}$

$* * * \Delta \lambda=\lambda_{\text {max }} \mathrm{S}-\boldsymbol{\lambda}_{\text {max }} \mathrm{B}$
}

\section{Stability of formed azo dye}

The color development showed that the colour started to form within about five minutes. The formation of azo dye being complete after 15 minutes and the absorbance of the coloured species remained constant for at least 25 minutes, this stability period is sufficient for several measurements (Table4). 
Table 4. Effect of time and OMCl amount on A

\begin{tabular}{|c||c|c|c|c|c|c|c|c|c|}
\hline \multirow{2}{*}{$\begin{array}{c}\mu g \text { of } \\
\text { OMCl } \\
\text { present }\end{array}$} & \multicolumn{8}{|c|}{ Absorbance / minute standing time } \\
\cline { 2 - 11 } & $\mathbf{5}$ & $\mathbf{1 0}$ & $\mathbf{1 5}$ & $\mathbf{2 0}$ & $\mathbf{2 5}$ & $\mathbf{3 0}$ & $\mathbf{4 0}$ & $\mathbf{5 0}$ & $\mathbf{6 0}$ \\
\hline $\mathbf{5 0}$ & 0.129 & 0.187 & 0.211 & 0.211 & 0.207 & 0.203 & 0.197 & 0.178 & 0.168 \\
\hline $\mathbf{1 0 0}$ & 0.249 & 0.277 & 0.307 & 0.309 & 0.311 & 0.310 & 0.299 & 0.276 & 0.255 \\
\hline
\end{tabular}

\section{Accuracy and precision}

In order to check the accuracy and precision of the proposed method three various amountes of $\mathrm{OMCl}$ where taken and determined. The results illustrated in tables show that suggested method gave satisfactory.

Table 5. Accuracy and precision of the method

\begin{tabular}{|c|c|c||}
\hline $\begin{array}{c}\text { Amount of } \mathrm{OMCl} \text { taken, } \\
\mu \mathrm{g} / 25 \mathrm{ml}\end{array}$ & Relative error, \%* & $\begin{array}{c}\text { Relative standard } \\
\text { deviation, \%* }\end{array}$ \\
\hline 40 & +0.97 & \pm 1.57 \\
\hline 100 & +0.21 & \pm 0.32 \\
\hline 200 & -0.28 & \pm 0.27 \\
\hline
\end{tabular}

*Average of 5 determinations.

Nature of the dye.

Job's method indicated that the azo dye has a composition of $1: 1 \mathrm{OMCl}$ to diazotized sulphanilic acid $[$ R](Fig.3).

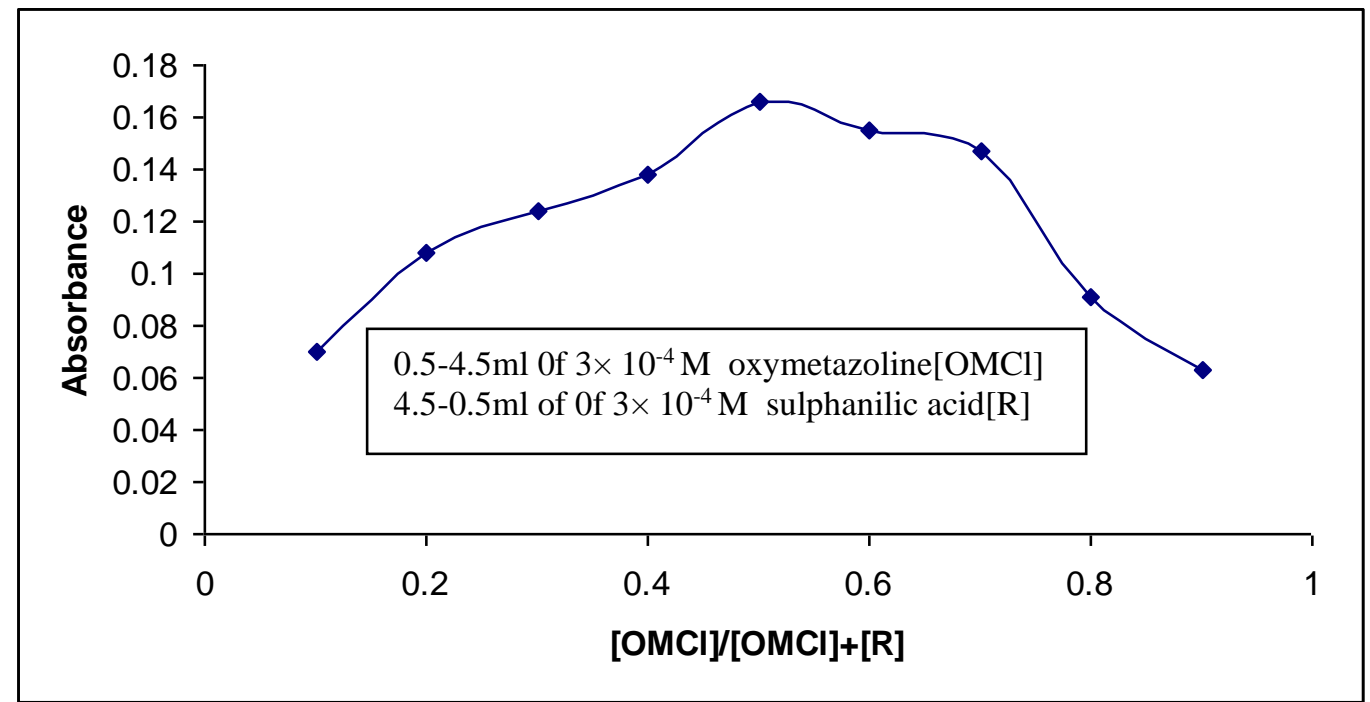

Fig. 3: Job's plot for OMCI - sulphanilic acid 
Hence the dye might be the following structure.<smiles>Cc1cc(C(C)(C)C)c(ON=Nc2ccc(S(=O)(=O)O)cc2)c(C)c1CC1=NCCN1</smiles>

Fig. 5: The possible structure of the orange azo dye

\section{Interference}

The excipients which frequently accompany pharmaceutical formulation are studied by adding three various amounts $(100,500$ and $1000 \mu \mathrm{g})$ to $100 \mu \mathrm{g} \mathrm{OMCl}$ (Table 6).

Table 6. Effect of foreign compounds for assay of $\mathrm{OMCl}$

\begin{tabular}{|c|c|c|c|}
\hline \multirow{2}{*}{$\begin{array}{c}\text { Foreign } \\
\text { compound }\end{array}$} & \multicolumn{3}{|c|}{$\begin{array}{c}\text { Recovery }(\boldsymbol{\%}) \text { of } \mathbf{1 0 0} \boldsymbol{\mu g} \text { OMCl per } \boldsymbol{\mu g} \text { foreign compound } \\
\text { added in } \mathbf{2 5} \mathbf{~ m l}\end{array}$} \\
\cline { 2 - 4 } & $\mathbf{1 0 0}$ & $\mathbf{5 0 0}$ & $\mathbf{1 0 0 0}$ \\
\hline Glucose & 105.5 & 98.5 & 96.2 \\
\hline Lactose & 99.2 & 95.1 & 99.6 \\
\hline Starch & 98.8 & 102.9 & 101.1 \\
\hline $\begin{array}{c}\text { Gum Arabic } \\
\text { (Acacia) }\end{array}$ & 102.9 & 105.5 & 102.6 \\
\hline
\end{tabular}

Table 6 with its results indicated that there is no interference of any excipients added to the determination of $\mathrm{OMCl}$ using the suggested procedure.

\section{Applications part}

The formulations of $\mathrm{OMCl}$ as nasal drops have been selected in our applications part. Good recoveries are obtained (Table 7).

Table7. Result of applications part.

\begin{tabular}{|c|c|c|c|}
\hline \multirow{2}{*}{ Drug } & $\begin{array}{c}\boldsymbol{\mu} \text { ( OMCl } \\
\text { present/25ml }\end{array}$ & $\begin{array}{c}\boldsymbol{\mu g} \text { OMCl } \\
\text { measured/25ml }\end{array}$ & Recovery, \% \\
\hline \multirow{3}{*}{$\begin{array}{c}\text { Nazordin 0.05\% } \\
\text { S.D.I-Iraq }\end{array}$} & 50 & 52.2 & 104.5 \\
\cline { 2 - 4 } & 100 & 104.4 & 104.4 \\
\cline { 2 - 4 } Oxymet 0.025\% & 200 & 195.3 & 97.6 \\
\cline { 2 - 4 } Pharaonia(Egypt) & 50 & 49.5 & 99.0 \\
\cline { 2 - 4 } & 100 & 105.2 & 105.2 \\
\hline
\end{tabular}

*Average of three determinations. 


\section{Evaluation of the proposed method}

In order to prove that the suggested method can be applied to the determination of $\mathrm{OMCl}$ in formulations without interferences, a standard addition method is applied.

The results in Fig. 6 and Table 8 shows that there is no significant different between the amounts taken and experimental results.
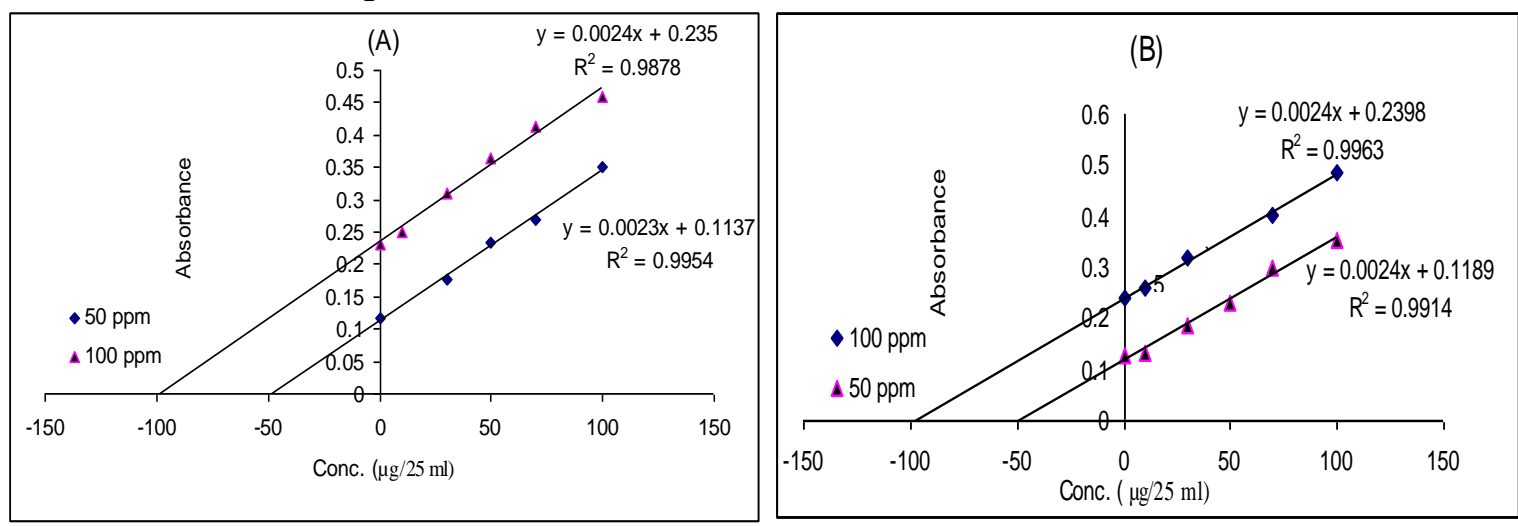

Fig. 6: Calibration standard addition graphs for the determination of $\mathrm{OMCl}$ in Nazordin [A] and Oxymet [B]

Table 8. The results of standard addition method

\begin{tabular}{|c|c|c|c|}
\hline \multirow{2}{*}{ Drug } & $\begin{array}{c}\mu \mathrm{g} \text { OMCl } \\
\text { present/25ml }\end{array}$ & $\begin{array}{c}\mu \mathrm{g} \text { OMCl } \\
\text { measured/25m } \\
\text { l }\end{array}$ & $\begin{array}{c}\text { Recovery, } \\
\%\end{array}$ \\
\hline \multirow{2}{*}{$\begin{array}{c}\text { Nazordin 0.05\% } \\
\text { S.D.I-Iraq }\end{array}$} & 50 & 49.4 & 98.8 \\
\cline { 2 - 4 } & 100 & 97.9 & 97.9 \\
\hline $\begin{array}{c}\text { Oxymet 0.025\% } \\
\text { Pharaonia(Egypt) }\end{array}$ & 50 & 49.5 & 99.0 \\
\cline { 2 - 4 } & 100 & 99.9 & 99.9 \\
\hline
\end{tabular}

* Average of three determinations

\section{Varible Comparison}

The various analytical parameters for our method and the same parameters for other literature methods $(14,16)$ have been calculated and illustrated in Table 9. 
Table 9. Comparison of the methods

\begin{tabular}{|c|c|c|c|}
\hline Anal. Parameters & Present method & Lit. method ${ }^{(16)}$ & Lit. method $(14)$ \\
\hline $\mathrm{pH}$ & 11.73 & $\ldots$ & $\ldots$ \\
\hline Temperature $\left(\mathrm{C}^{\circ}\right)$ & $\begin{array}{c}\text { At room } \\
\text { temperature }\end{array}$ & 70 & 70 \\
\hline$\lambda_{\max (\mathrm{nm})}$ & 496 & 480 & 510 \\
\hline Medium of reaction & Aqueous & Aqueous & Aqueous \\
\hline Type of reaction & Diazo coupling & Oxidative coupling & Redox reactions \\
\hline Reagent & $\begin{array}{c}\text { Diazotised } \\
\text { sulphanilic acid }\end{array}$ & 4-Amino- antipyrine & 1,10-phenathroline \\
\hline Beer's law range (ppm) & $0.8-16$ & $1-20$ & $0.1-7$ \\
\hline $\begin{array}{l}\text { Molar absorptivity } \\
\left(1 . \mathrm{mol}^{-1} \cdot \mathrm{cm}^{-1}\right)\end{array}$ & $2.03 \times 10^{4}$ & $5.34 \times 10^{4}$ & $5.74 \times 10^{4}$ \\
\hline Nature of the dye & $1: 1$ & $1: 2$ & $1: 1$ \\
\hline $\begin{array}{l}\text { Application of the } \\
\text { method }\end{array}$ & $\begin{array}{l}\text { Nazordin } 0.05 \% \\
\text { Oxymet } 0.025 \%\end{array}$ & $\begin{array}{l}\text { Nazordin } 0.05 \% \\
\text { Oxymet } 0.025 \%\end{array}$ & $\begin{array}{l}\text { Nazordin } 0.05 \% \\
\text { Oxymet } 0.025 \%\end{array}$ \\
\hline
\end{tabular}

\section{Conclusion}

The proposed method is simple, sensitive and there is no previous separation or temperature controlled. The method has been successfully applied to the determination of $\mathrm{OMCl}$ in various pharmaceutical preparations.

\section{References}

1. British Pharmacopeia on CD-ROM, $3^{\text {rd }}$ Edn., System Simulation Ltd, the stationary office, London(2000).

2. Stanisz B., Acta pol. Pharm. Drug Res., 59:19-23(2002).

3.Katz R.I., Hovagim A.R., Finkelstein H.S., J.Clin.Anesth.,2:16-20(1990).

4. http://www.wikipedia.org/wiki/oxymetazoline, (2008).

5. Katzung B.G.," Basic and Clinical Pharmacology". $9^{\text {th }}$ edn. McGraw Hill Companies, New York, 134(2004).

6. Dwivedi P.K., Dubey B.K. and Shukla I.C., Oriental J. Chem.,22(1), (2006)

(Abstract) .

7. Issa Y.M. and Zayed S.I.M., Anal.Sci.,20:297 (2004).

8. Stanszis B.and Nowinski W., Acta Pol. Pharm., 57:339-401(2000).

9. Hoffmann T.J., Thompson R.D. and Seifert J.R., Drug Development and Industrial Pharmacy , 15:743-757 (1989).

10. Sane RT., Joshi LS., Ladage KD., Kothurkar RM.and Bhate VR., Ind.J. Pharm.Sci.,52: 38-39 (1990).

11. Garcia-Compana A.M., Sendra J.M.B., Vargas M.P.B., Baeyens W.R.G. and Zhang X., Anal.Chim.Acta, 516:245-249 (2004).

12. Snakar D.G., Sastry C.S.P., Ready M.N. and Prasad S.T.R., Ind. J. Pharm. Sci., 49-69 (1987).

13. Snakar D.G., Sastry C.S.P., Ready M.N. and Akuna M., Ind. J. Pharm. Sci., 50: 178-180 (1988).

14. Al-Sabha T.N and Rasheed B.A., JJC., 6, 403-411(2011)

15. Al-Neaimy U.I., Ph. D., Thesis, College of Education, University of Mosul (2006) (in Arabic)

16. Zakaria S.A., Raf. J. Sci., 22:97-108 (2011).

17. Ahmad A.K., Hessan Y.I. and Bashir W.A., Analyst, 111: 243- 244 (1986). 